\title{
The Abundance, Autumn Migration, Population Structure and Body Dimensions of the Harvest Mouse in Northern Finland
}

\author{
Pentti KOSKELA \& Pirkko VIRO
}

\begin{abstract}
Koskela P. \& Viro P., 1976. The abundance, autumn migration, population structure and body dimensions of the harvest mouse in Northern Finland. Acta theriol., 21, 28: 375-386 [With 3 Tables \& 7 Figs.].

A special capturing fence was used to study the abundance and autumn migration of the harvest mouse Micromys minutus ( $\mathrm{P}$ a 11 a s, $1778)$ in 1972 and 1973 at Haapavesi, Northern Finland $\left(64^{\circ} \mathrm{N}\right)$. A considerable decline in numbers was noted from $63 \%$ of all small mammal specimens in 1972 to $13 \%$ in 1973. Migration from the fields (summer biotope) to the river-bank meadows was observed in late September and early October in both years. This migration was induced by the onset of frosts. It took place during twilight and at night and only at temperatures above $0^{\circ} \mathrm{C}$. Migration stopped when once the period of frost and snow had begun. The proportion of overwintered specimens was $4.4 \%$ in autumn 1972 , and the male-female ratio was $105: 123$. The last pregnant female $(55 \mathrm{~mm} / 5.5 \mathrm{~g})$ was captured on 11 th October. The body length of the harvest mice varied from 47.0 to 71.0 $\mathrm{mm}$, being $59.1 \mathrm{~mm}$ on average, and their weight from 3.5 to $12.5 \mathrm{~g}$, the average being $6.3 \mathrm{~g}$.

[Dept. Zool., Univ. Oulu, SF-90100 Oulu, Finland]
\end{abstract}

\section{INTRODUCTION}

The distribution area of the harvest mouse, Micromys minutus ( $\mathrm{P}$ a ll a s, 1778) extends from Central and Northern Europe through Central Asia all the way to the coast of the Pacific Ocean and to Japan (P i echocki, 1958). According to Siivonen (1974) the species has its most nerthern occurrences in Finland, on a line between Kuusamo and Rovaniemi $\left(66^{\circ} \mathrm{N}\right)$. It has not been found in Sweden and Norway. The harvest mouse has been known in the vicinity of Oulu $\left(65^{\circ} \mathrm{N}\right)$ and at Haapavesi $\left(64^{\circ} \mathrm{N}\right)$ from the beginning of this century ( $\mathrm{Kivirikko}$, 1909; P a r vel a, 1921, 1922).

The occurrences of the harvest mouse are often sporadic, but abundant (e.g. Kaikusalo, 1972). Such a find was made in 1972 and 1973 at Haapavesi in connection with work on the common frog ( $\mathrm{Koskela}$ \& P a s a n e n, 1974), which involved the use of a special capturing fence to trace the migration of the frogs to their wintering places in the river, a subsidiary catch of over one thousand small mammals being obtained 
including almost 400 harvest mice. This enabled the small mammal fauna of this area to be described, along with the timing of the autumn migration, the population structure and the body dimensions in the various species. The details are presented for the case of the harvest mouse in this paper.

\section{STUDY AREA AND METHODS}

The study area is situated on the south shore of Mieluskoski, on the Pyhäjoki water course, near Haapavesi. The capturing area is on the edge of a strip of cultivated land $0.5 \mathrm{~km}$ broad. In the south the field is bordered by damp heath forest. The overall length of the capturing fence was $315 \mathrm{~m}$, the first $90 \mathrm{~m}$ of which (part I) bordered directly on the cultivated area. Part II, also $90 \mathrm{~m}$, was situated in a dense grove of alders (Alnus incana) on the river bank $10-20 \mathrm{~m}$ from the field and part III (Fig. 1), $135 \mathrm{~m}$, bordered on a grassy area which had formerly been a timber stacking site $(50 \mathrm{~m}$ from the field). The fields near the capturing area were abandoned 3-4 years ago and are now occupied by couch grass (Elytrigia repens).

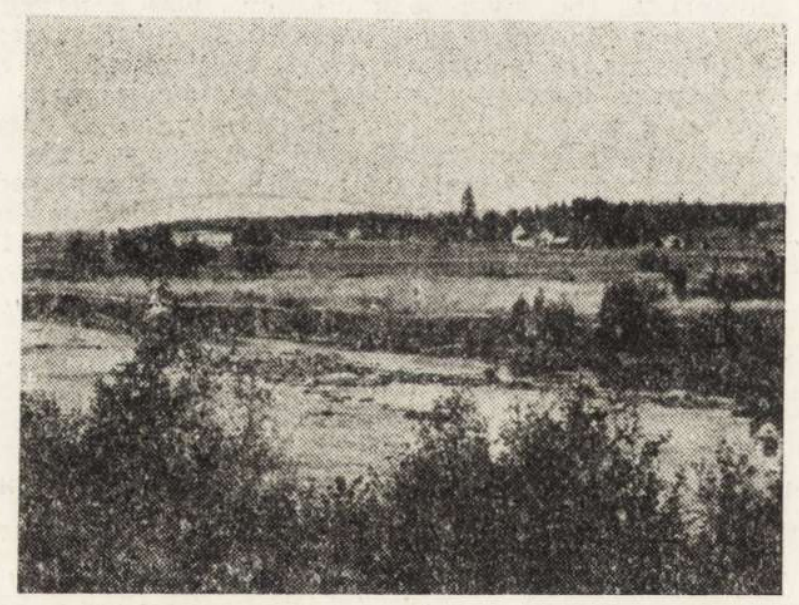

Fig. 1. Capturing fence (part III) on the shore at Mieluskoski.

The fence was built on the river bank $1-5 \mathrm{~m}$ from the water's edge ( $\mathrm{K}$ os k e la \& P a s a n e n, 1974), and plastic pails $(26 \times 24 \mathrm{~cm})$ were let into ground beside it at $10-15 \mathrm{~m}$ intervals on the field side adjacent to $5 \mathrm{~m}$ long guiding fences. Each pail had $10 \mathrm{~cm}$ of water in the bottom. After reaching the shore the small mammals and frogs started following the fence and fell into the pails. The pails were emptied at least four times a day $(6.00,12.00,18.00$ and 24.00$)$ and at hourly intervals throughout the day during some periods. Capturing began at the end of August and finished at the end of October. The catch included 306 harvest mice in 1972 and 85 in 1973.

The harvest mouse scarcely ever falls into a snap trap, so that the method used here proved to be very suitable for capturing harvest mice and other mammals 
(e.g., Sorex minutissimus and Sorex minutus), which are otherwise difficult to catch. It should be mentioned that Department of Zoology, University of Oulu, has been making snap trap catches in different biotopes in the vicinity of Oulu from the late 1960 's, but only a few harvest mouse specimens have ever been caught, $0.2 \%$ of the total catch of approx. 6000 small mammals.

A Lambrecht thermograph was used to measure the air temperature. Daily precipitation figures were obtained from the weather station at Haapavesi, about $12 \mathrm{~km}$ from the study area.

The sex of the mice and the reproductive stage of the females were determined, the specimens were weighed to the nearest $0.5 \mathrm{~g}$, the body and tail length measured to the nearest $0.5 \mathrm{~mm}$ and the length of the hind foot to the nearest 0.1 $\mathrm{mm}$. The body length was measured from the tip of the snout to the anus and that of the hind foot from the heel to the tip of the longest toe (S i iv o n e n, '1974).

\section{RESULTS AND DISCUSSION}

\section{The Abundance of the Harvest Mouse in the Small Mammal Fauna}

The eleven small mammal species captured and their numbers are shown in Table 1 . The harvest mouse population was yery numerous

Table 1

Proportions of small mammals $(\%)$ in the study area in 1972 and 1973.

\begin{tabular}{lrrr}
\hline Species & $1972, \%$ & $1973, \%$ & $1972-1973, \%$ \\
\hline Sorex araneus & 18.7 & 15.6 & 16.9 \\
S. caecutiens & 1.5 & 0.7 & 1.1 \\
S. minutus & 9.0 & 6.6 & 7.6 \\
S. minutissimus & 0.4 & 0.0 & 0.2 \\
Neomys fodiens & 1.8 & 0.9 & 1.3 \\
Clethrionomys glareolus & 1.8 & 3.9 & 3.0 \\
Microtus agrestis & 6.0 & 56.2 & 34.4 \\
Arvicola terrestris & 0.2 & 0.7 & 0.5 \\
Mus musculus & 0.6 & 2.6 & 1.7 \\
Micromys minutus & 59.8 & 12,7 & 33.1 \\
Rattus norvegicus & 0.2 & 0.1 & 0.2 \\
Total & 100.0 & 100.0 & 100.0 \\
Specimens & 512 & 669 & 1181 \\
\hline
\end{tabular}

in 1972 , comprising $60 \%$ of all the small mammals. An obvious population explosion had occurred during the following year, however, as the proportion was down to approx. $13 \%$ of the small mammal fauna by autumn 1973 , which amounted to only about $24 \%$ of the previous year's catch, while the field vole population (Microtus agrestis) had multiplied at the same time. The fields near the study area had been abandoned since 1968-1969. Evidently those fields occupied by the couch grass offered the harvest mouse a good environment for reproduction, until by 1972 it had became the main species. 
In Southern and Central Ostrobothnia and in the vicinity of Oulu in Northern Ostrobothnia the harvest mouse accounts for $1-3 \%$ of the small mammals in the diet of birds of prey ( $\mathrm{Sulkava} \& \mathrm{Sulkava}$, 1967, 1971; Grönlund \& Mikkola, 1969; Mikkola, 1970, 1971). These studies comprise a total of 7000 small mammal individuals. On the basis of the composition of the food of the predators studied and the situation of their nests, only a third of the prey must originate from

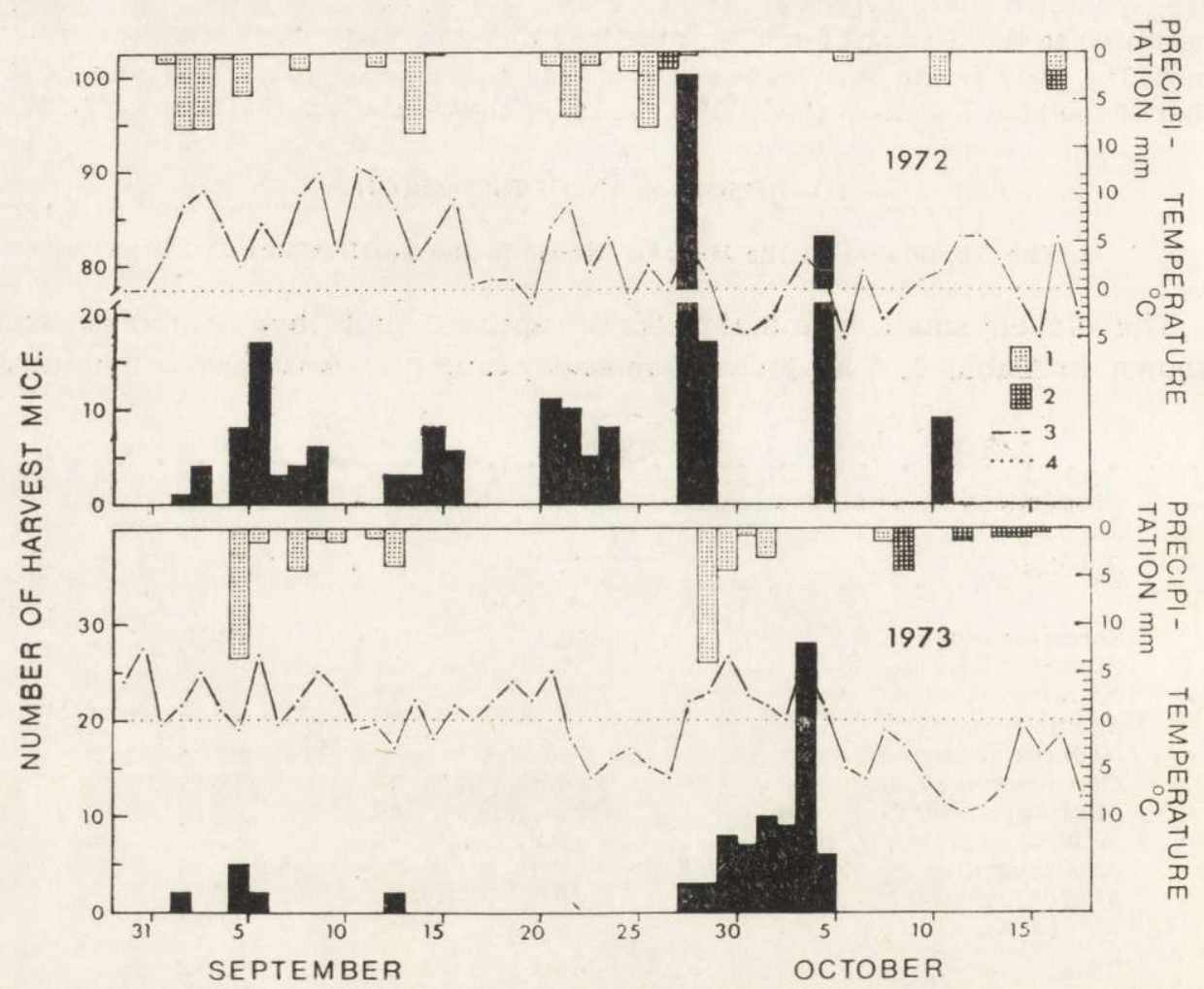

Fig. 2. Daily numbers of harvest mice trapped and weather conditions in 1972 and 1973. $1=$ rainfall $\mathrm{mm}, 2=$ snowfall $\mathrm{mm}, 3=$ minimum air temperature at ground level, $4=0^{\circ} \mathrm{C}$ level.

fields and meadows, i.e. from the areas where the harvest mouse mostly lives. Thus the hypothetical value for the proportion of the harvest mouse in the diet of birds of prey within the fields of this region is $3-9 \%$, which is still lower than the value found in this study after the population explosion, $13 \%$. However, no explanation is available concerning the extent to which the abundance of the harvest mouse in the diet of birds of prey correlates with its situation in nature. 


\section{Autumn Migration}

A. General Pattern and Timing of Migration

The harvest mouse catch was rather similar at different points in the capturing fence, indicating a broad migration front:

$\begin{array}{llll} & \text { I }(90 \mathrm{~m}) & \text { II }(90 \mathrm{~m}) & \text { III }(135 \mathrm{~m}) \\ 1972 & 92 & 80 & 134 \text { specimens } \\ 1973 & 24 & 28 & 33 \text { specimens }\end{array}$

The daily results and weather conditions are shown in Figure 2 and the catch is classified into five-day sections in Table 2. Harvest mice entered the traps from the beginning of September to the beginning of October. In 1973 almost all the harvest mice reached the capturing area within the period 28.9. - 5.10., only a few individuals being caught earlier in September. In the preceding year harvest mice appeared in rather large numbers throughout September. This difference may be due to the differences in the population size.

Table 2

The harvest mouse catch classified into 5-day sections.

\begin{tabular}{rrr}
\hline & \multicolumn{2}{c}{ Specimens } \\
Date & 1972 & 1973 \\
\hline $1-5.9$. & 13 & 7 \\
$6-10.9$ & 30 & 2 \\
$11-15.9$. & 14 & 2 \\
$16-20.9$. & 6 & 0 \\
$21-25.9$ & 34 & 0 \\
$26-30.9$. & 117 & 14 \\
$1-5.10$. & 83 & 54 \\
$6-10.10$. & 0 & 6 \\
$11-15.10$. & 9 & 0 \\
Total & 306 & 85 \\
\hline
\end{tabular}

In both years a clear migration peak occured at the same time, at the end of September and beginning of October. One might even speak of a mass migration in 1972, for on two nights (28th/29th September and before midnight on 5th October) more mice from the nearby fields gathered on the bank in the capturing area than during the whole of the remaining time.

\section{B. Diel Activity during Migration}

The harvest mice migrated almost exclusively during twilight and at night, between 19.00 and 3.00 hours, mostly in the period before mid- 
night (Fig. 3). Only three out of the 391 specimens were captured during the daylight hours.

The timing of locomotor activity in the harvest mouse agrees well with the results found in France in a constant environment in October by $\mathrm{S}$ a in t Girons (1959), although activity continues after midnight as a rule in the laboratory.

It is known that the actogram is fixed only under experimental conditions, and that in nature many ecological factors serve to modify the activity rhythm. In this work temperature was found to regulate migration. Obviously the low night temperatures were generally the cause of the inactivity after midnight.

According to $\mathrm{S}$ a in $\mathrm{t}$ Girons $(1959,1966)$ the activity of the harvest mouse is polyphasic like that of most mammals.

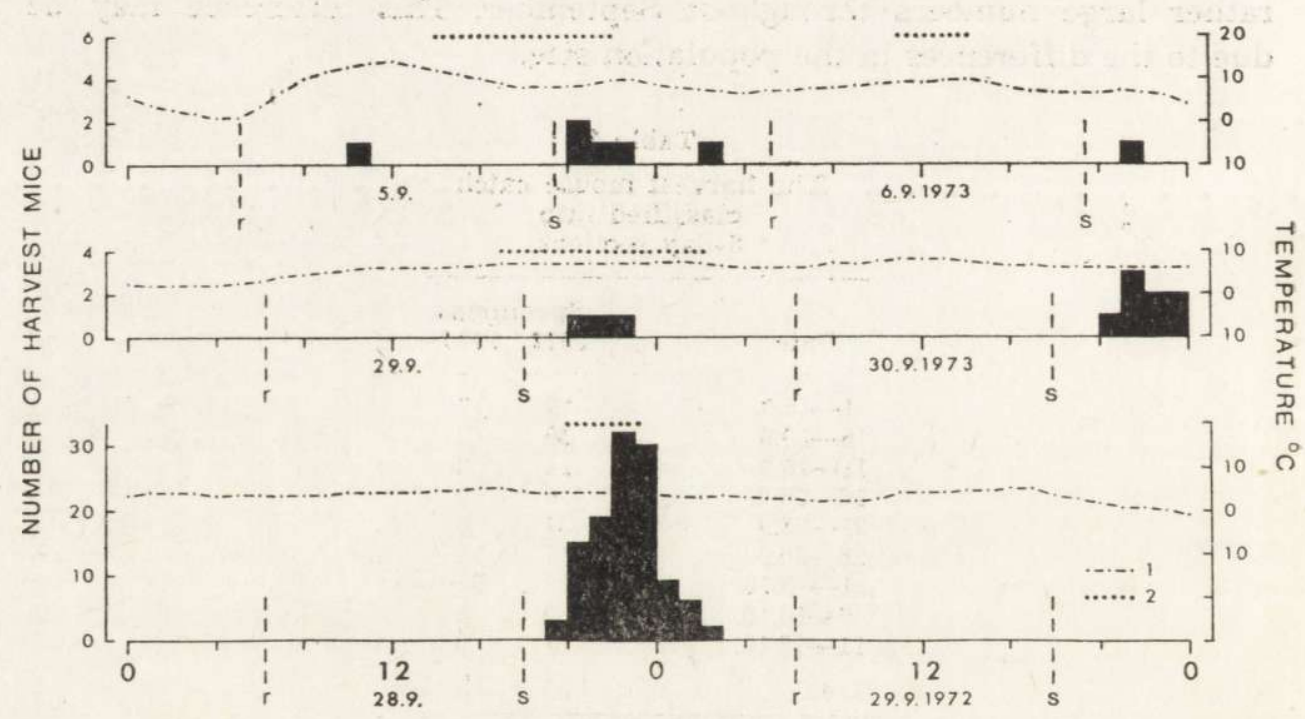

Fig. 3. Diel migration activity patterns for six days, 28-29.9.1972, 5-6.9. and $29-30.9 .1973$. $1=$ air temperature at ground level, $2=$ duration of rain.

$$
\mathrm{r}=\text { sunrise, } \mathrm{s}=\text { sunset }
$$

C. Factors Influencing on Migration

Many small mammals change their habitat with the seasons. B r i e s e \& S m ith (1974) report emigration as the cause of a $22-50 \%$ decline in the numbers of nine different species in a study area in South Carolina, the timing and magnitude of such emigrations tending to vary with the species.

The autumn and spring migration of small mammals generally re- 
presents a change between the summer and winter biotopes: A clear difference between summer and winter habitats has been found in the such mammals as the Norwegian lemming, Lemmus lemmus (K a le la et al. 1971), the wood lemming, Myopus schisticolor (e.g. K a l a la et al. 1963), the root vole, Microtus oeconomus ( $\mathrm{T}$ a s t, 1968; K o st i a n, 1970) and the wood mouse, Apodemus sylvaticus (T a n to n, 1969). The migration may take on the nature of an emigration due to accentuated growth in the population and the associated food shortage e.g. in the Norwegian lemming ( $\mathrm{K}$ a le la, 1972).

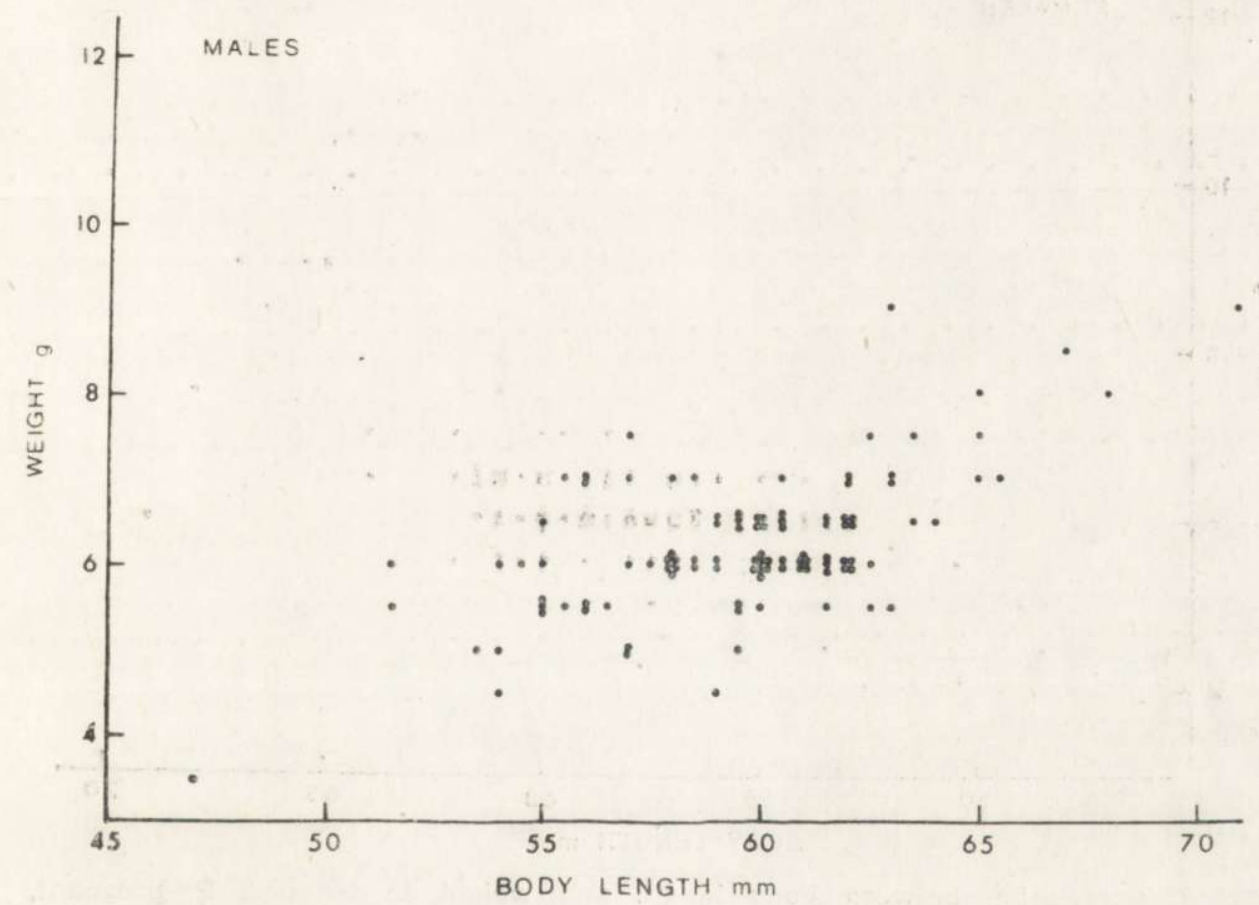

Fig. 4. Correlation between body length and weight in males.

The harvest mouse population was very large in 1972 , but had decreased by $76 \%$ by autumn 1973 . Because the migration peak in 1972 and the maximum migration figures in 1973 occurred at exactly the same time of year, this cannot be considered an emigration caused by overpopulation, but rather one from the summer biotope to the wintering area.

Since the catch was limited to the river bank, one cannot deduce whether migration was directed only towards the narrow riverside meadow (2-10 m wide), or whether the mice also migrated in the other directions and possibly to the other biotopes. 
The main migration began under the same weather conditions in both years (Fig. 2), i.e. after the first indications of winter, the first frosts. In autumn 1972 migration was also preceded by a snowfall. The harvest mice migrated only when the temperature was over $0^{\circ} \mathrm{C}$. After the mass migration night of 28 th -29 th September 1972 migration stopped due to frosts, but as soon as the temperature rose sufficiently again large numbers were observed on the 5th October and some individuals still on 11 th October, after which migration apparently ceased.

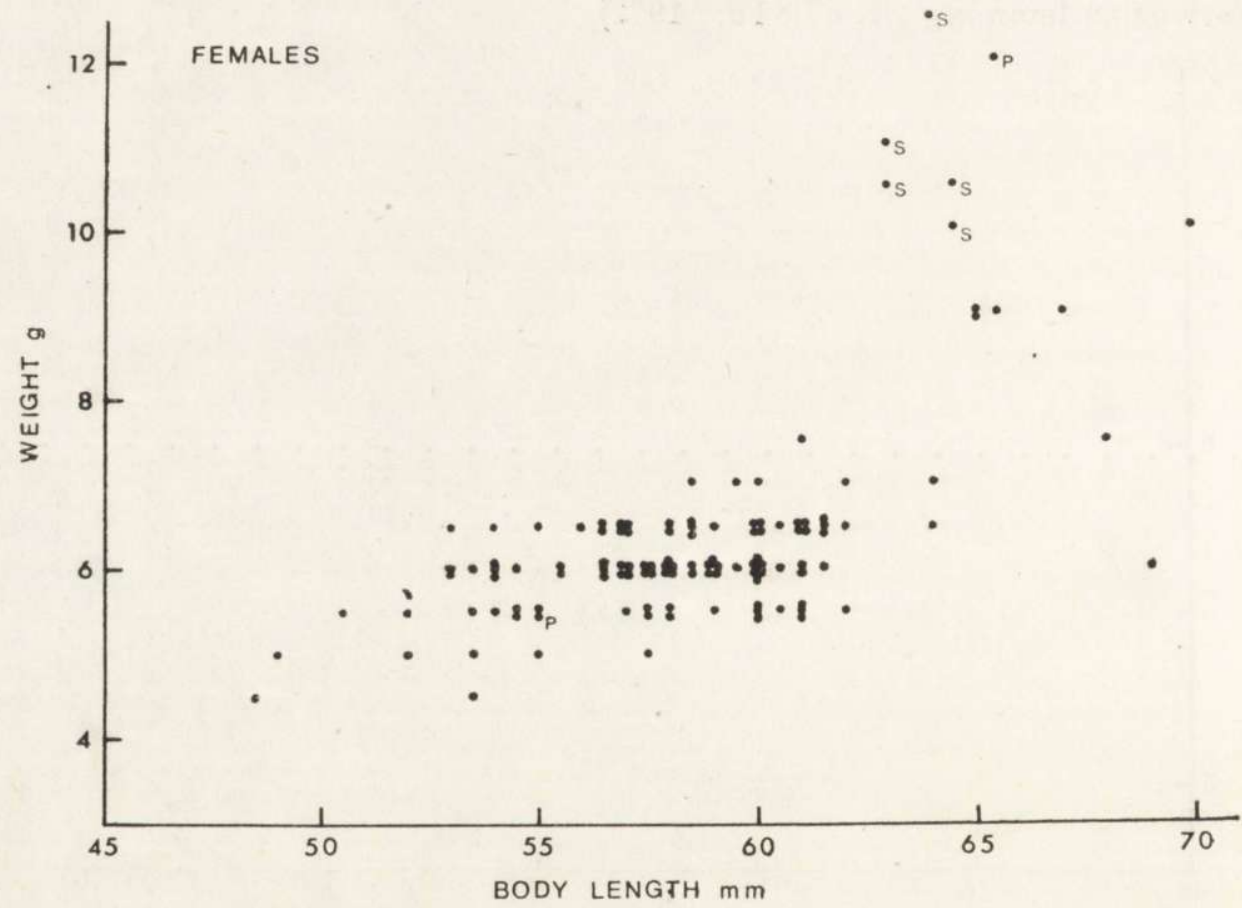

Fig. 5. Correlation between body length and weight in females. $P=$ pregnant, $\mathrm{S}=$ suckling.

The period of permanent frost and snowfall began on 18.10.1972. In autumn 1973 the migration began on 28th September and continued up to 5 th October, whereupon the temperature fell below $0^{\circ} \mathrm{C}$, snowfall beginning on 9 th October. It should be added that during the migration nights in question in both autumns there was a rather strong wind (4$6 \mathrm{~m} / \mathrm{s}$ ), and connected with this a heavy fall of leaves from the trees, particularly from the birches (Betula pubescens). In the endphase of its migration (onset of snowfall) the autumn migration of the harvest mouse resembles that of the Norwegian lemming.

It is known that harvest mice take refuge in grain stores and other 
similar places in autumn, but as far as the authors are aware no description has been given earlier of a demonstrable autumn migration.

\section{Population Structure}

There were 105 males and 123 females among the mice studied in 1972 (228 individuals). The sex-ratio varies a little in different areas. S o u thw ick (1955) reports a male-female ratio of $102: 80$ in an English harvest mouse population, $\mathrm{Kubik}(1952)$ a ratio $173: 134$ in a Polish population and $\mathrm{Br}$ e e \& $\mathrm{M}$ a a s s e n (1962) $74: 79$ in a Dutch population.

There were two pregnant females ( 5 and 7 embryos) and five lactating ones in the catch (Fig. 5). The smaller pregnant female (5 embryos) was

Table 3

Body dimensions. $\mathrm{M}=$ male (105 specimens), $\mathrm{F}=$ female (123 specimens), S.D. $=$ standard deviation.

\begin{tabular}{llcrl}
\hline Measurement & & Range & Mean & S.D. \\
\hline Body length, mm & M & $47.0-71.0$ & 59.6 & 3.53 \\
& F & $48.5-70.0$ & 58.6 & 3.79 \\
& Total & $47.0-71.0$ & 59.1 & 3.70 \\
\hline Body weight, g & M & $3.5-9.0$ & 6.3 & 0.83 \\
& F & $4.5-12.5$ & 6.4 & 1.33 \\
& Total & $3.5-12.5$ & 6.3 & 1.13 \\
\hline Hind foot length, mm & M & $11.0-14.5$ & 13.5 & 0.54 \\
& F & $12.2-14.4$ & 13.4 & 0.49 \\
& Total & $11.0-14.5$ & 13.4 & 0.51 \\
\hline Tail length, mm & M & $37.5-61.0$ & 50.0 & 4.34 \\
& F & $39.0-63.0$ & 49.9 & 4.08 \\
& Total & $37.5-63.0$ & 50.0 & 4.19 \\
\hline Tail index, $\%$ & M & $72.4-100.0$ & 83.8 & 5.99 \\
& F & $67.4-99.0$ & 85.3 & 5.91 \\
& Total & $67.4-100.0$ & 84.6 & 5.98 \\
\hline
\end{tabular}

$55 \mathrm{~mm}$ long and $5.5 \mathrm{~g}$ in weight, and was captured on 11th October. $55 \mathrm{~mm}$ is considered to be the lower size limit for mature females (S i i$\mathrm{v}$ o $\mathrm{n}$ en, 1974). Since the harvest mouse becomes mature at the age of 40-50 days (P i e chocki, 1958), individuals of $55 \mathrm{~mm}$ or less size can be considered younger than 2 months. $15.8 \%$ of the catch was composed of such individuals.

Eight females and twelve males from the part of the catch which was studied in detail had overwintered (cf. $\mathrm{K} \mathrm{u} \mathrm{b} \mathrm{i} \mathrm{k,} \mathrm{1952),} \mathrm{i.e.} \mathrm{the} \mathrm{proportion}$ of overwintered individuals in the population was $4.4 \%$. In $\mathrm{K} \mathrm{u} \mathrm{bi} \mathrm{k's}$ (1952) material, the majority of which was captured in August-November, the proportion of overwintered animals was only around $1 \%$. 


\section{Size of the Harvest Mouse}

The extreme values, the mean and standard deviations for the measurements are shown in Table 3 , the correlation between length and weight in Figures 4 and 5, and that between body length and tail length in Figures 6 and 7.

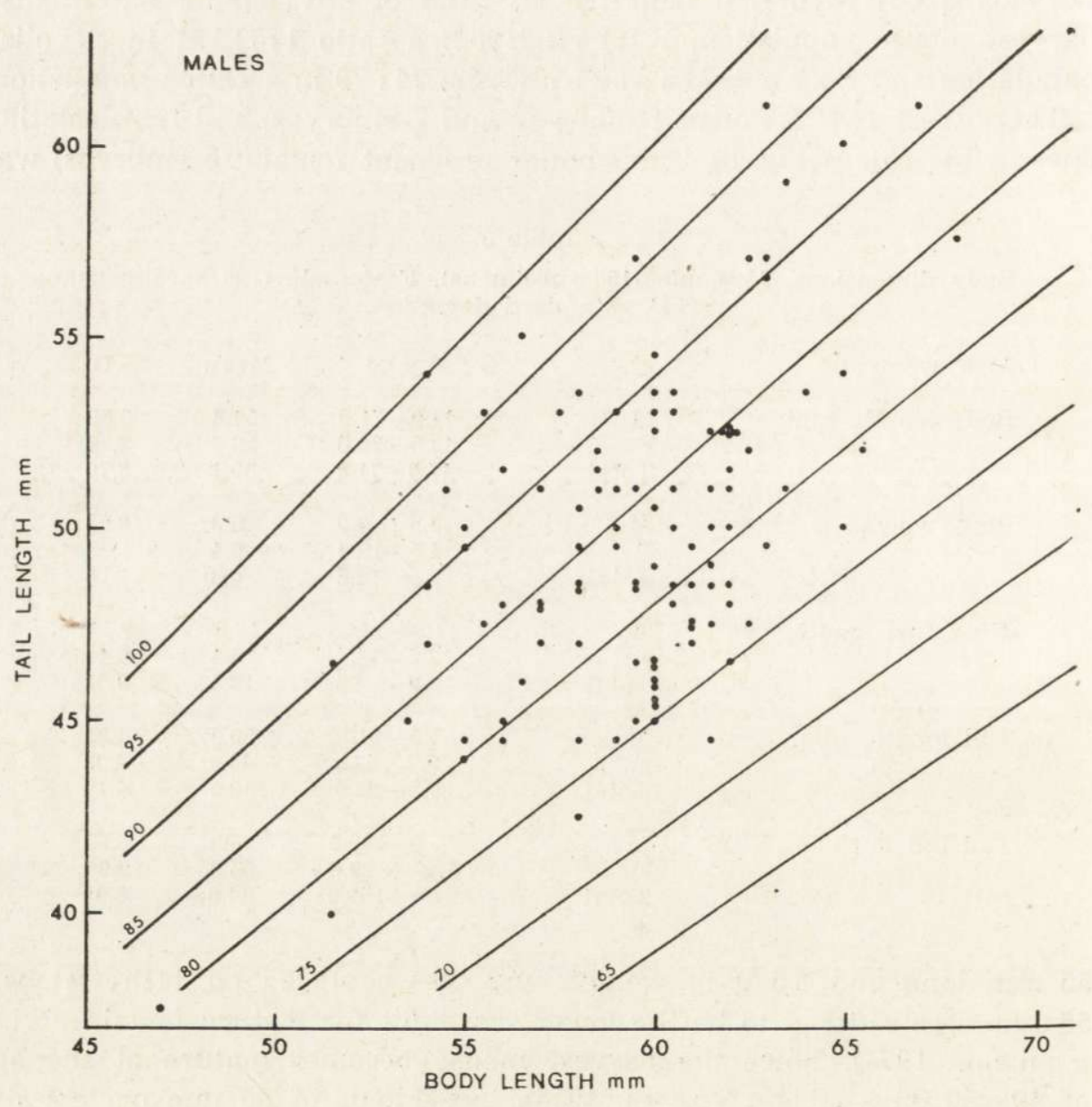

Fig. 6. Correlation between tail length and body length in males. The tail index (=tail length as a percentage of body length) is indicated by numbered diagonal lines.

The males were on the average $1.0 \mathrm{~mm}$ longer than the females $(t=2.08$, $p<0.05)$. The heaviest individual was a pregnant female. There was a positive correlation between body length and weight $(r=0.61, p<0.001)$, while the correlation between body length and tail length $(r=0.53$, 
$p<0.001)$ suggests that tail growth follows both overall growth and age. However, the negative correlation $(r=-0.24, p<0.001)$ between body length and the tail index shows that the growth of the tail is slower than

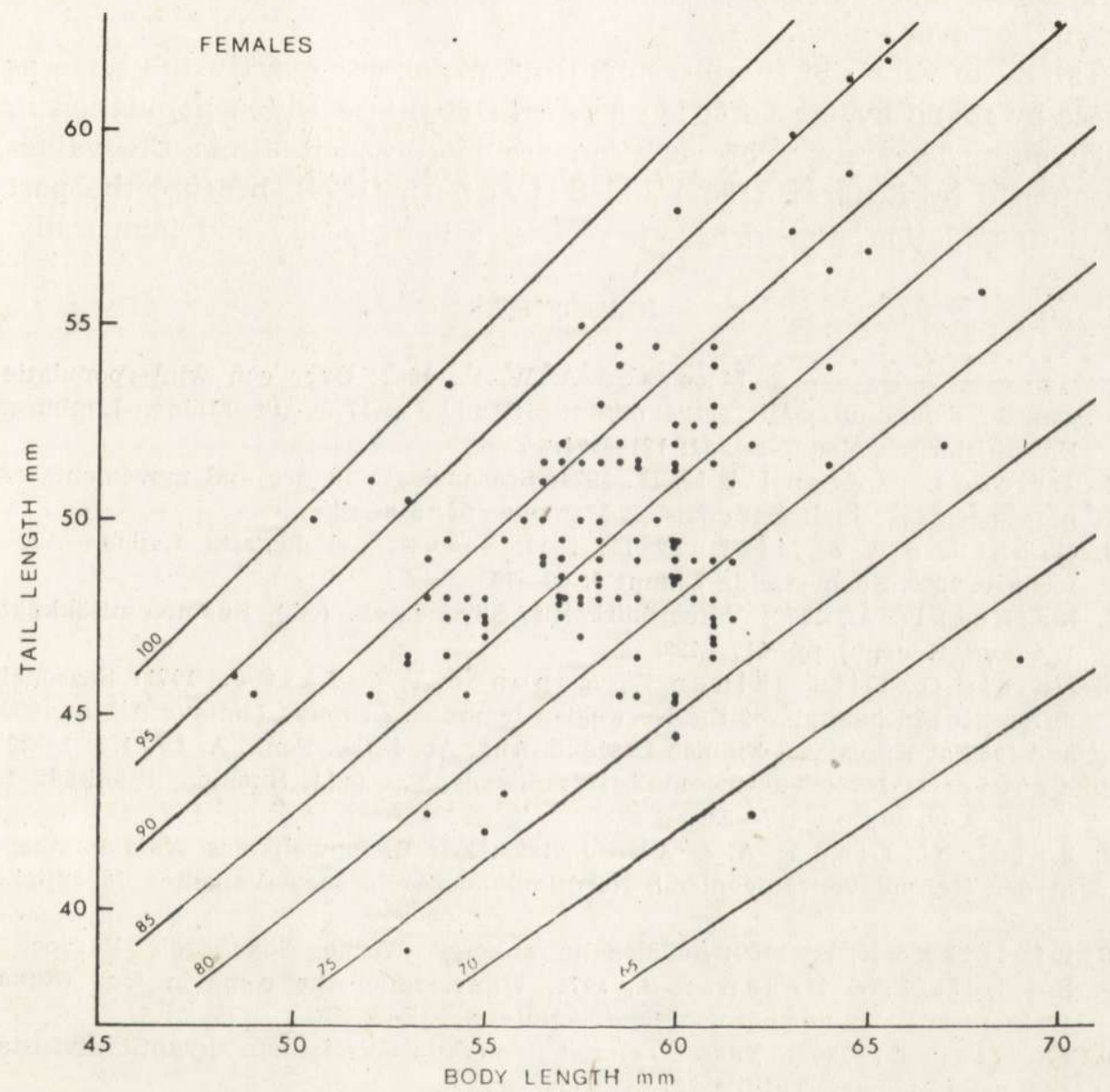

Fig. 7. Correlation between tail length and body length in females. Key as in Fig. 6.

that of the body. Thus this tail indices of the smallest harvest mice are the highest on average:

$\begin{array}{ccr}\text { Body length mm } & \text { Tail index \%, mean } & \mathrm{n} \\ -50.5 & 91.9 & 4 \\ 51.0-55.5 & 87.5 & 37 \\ 56.0-60.5 & 84.4 & 116 \\ 61.0-65.5 & 83.1 & 64 \\ 66.0- & 82.2 & 7\end{array}$


In its tail index the harvest mouse resembles the house mouse, Mus $m$. musculus (S i iv on en, 1954a, b). The difference in size between the sexes is also reflected in the tail index, which is $1.5 \%$ higher in the females than in the males $(t=1.91, p<0.10)$. The difference is not significant, however.

The mean values of the measurements are almost exactly the same as those by found by Bree \& M a a s s en (1962) in a Dutch population in midwinter. The ranges of variation are more concise than the values mentioned by K u bik (1952) and Siivonen (1974), because the part of the population studied here is restricted both locally and temporally.

\section{REFERENCES}

1. Bre e P. J. H., van \& M a a s sen A. W. P., 1962: Over een winterpopulatie van de dwergmuis, Micromys minutus (P a 11 as, 1778) uit Midden-Limburg. Naturhistorisch Maanblad, 51: 121-124.

2. Briese L. A. \& S mith M. H., 1974: Seasonal abundance and movements of nine species of small mammals. J. Mammal., 55: 615-629.

3. Grönlund S. \& Mikkola H., 1969: Suopöllön ekologiasta Lapuan Alajoella v. 1969. Suomenselän Linnut 4: $68-76$.

4. K a ik u s a lo A., 1972: Vaivaishiiri. [In: Siivonen, L. (ed.), Suomen nisäkkäät 1. Otava, Keuruu], pp. $417-428$.

5. Kalela O., Kilpeläinen L., Koponen T. \& Tast J., 1971: Seasonal differences in habitats of the Norwegian lemming, Lemmus lemmus (L.) in 1959 and 1960 at Kilpisjärvi Finnish Lapland. Ann. Acad. Sci. Fenn. A. IV. 178: 1-22.

6. Ka le la O., 1972: Tunturisopuli. [In: Siivonen, L. (ed.), Suomen nisäkkäät 1. Otava, Keuruu], pp. $317-330$.

7. Kalela O., Lind E. A. \& A ho J., 1963: Zur Biotopwahl des Waldiemmings in der Gegend von Rovaniemi, Nordfinnland. Arch. soc. "Vanamo" 18 suppl.: $39-46$.

8. Kivirikko K. E., 1909: Suomen luurankoiset. Werner Söderström, Porvoo.

9. Koskela P. \& Pasanen S., 1974: Wintering of the common frog (Rana temporaria L). in northern Finland. Aquilo, Ser. Zool. 15: 1-17.

10. Kostian E., 1968: Vaasan saariston pikkunisäkäsfaunan kvantitatiivisista suhteista. Luonnon Tutkija 72: 147-153.

11. Kostian E. 1970: Habitat requirements and breeding biology of the Root Vole (Microtus oeconomus (Pallas)), on shore meadows in the Gulf of Bothnia, Finland. Ann. Zool. Fennici 7: 329-340.

12. Kubik J., 1952: Micromys minutus Pall. in Naturschutzpark von Białowieża. Annls Univ. M. Curie-Skłodowska, sec. C, 7: 449-495.

13. Mikkola H. 1970: On the activity and food of the Pygmy Owl Glaucidium passerinum during breeding. Ornis Fennica 47: 10-14.

14. Mikkola H., 1971: Zur Ernährung der Sperbereule (Surnia ulula) zur Brutzeit. Angewandte Ornithologie 3: 133-141.

15. P a rvela A. A., 1921: Vaivaishiiriä Oulun seudulla. Luonnon Ystävä 25: 61 .

16. P a rvela A. A., 1922: Vaivaishiiriä Oulussa. Luonnon Ystävä 26: 55.

17. P iechocki R., 1958: Die Zwergmaus. A. Ziemsen Verlag: 1-56. Wittenberg Lutherstadt. 
18. S a in t Gir on $\mathrm{s}$ M. C., 1959: Les caractéristiques du rythme nycthéméral ches quelques petits Mammifères. Mammalia 23: 245-276.

19. S a int Girons M. C., 1966: Le rythme circadien de l'activité ches les Mammifères Holarctiques. Mém. Mus. Nation. Hist. Nat. Ser. A, Zool. 40: 101-187.

20. S i i v o n en L., 1954a: Nisäkästuntemuksen perusedellytyksistä. Luonnon Tutkija 58: $12-16$.

21. Siivonen L., 1954b: Über die Grössenvariationen der Säugetiere und die Sorex macropygmaeus Mill.-Frage in Fennoskandien. Ann. Acad. Scient. Fennicae A. IV. 21: 1-22.

22. S i iv o n e n L., 1974: Pohjolan nisäkkäät. Otava, Keuruu.

23. Southwick C. H., 1955: The abundance and distribution of harvest mice (Micromys minutus) in corn ricks near Oxford. Proc. zool. Soc. Lond., 126: 449 $-452$.

24. Sulkava P. \& Sulkava S., 1971: Die nistzeitliche Nahrung des Rauhfusskauzes Aegolius funereus in Finland 1958-1967. Ornis Fennica 48: 117-123.

25. Sulkava S. \& Sulkava P., 1967: On the small-mammal fauna of Southern Ostrobothnia. Aquilo, Ser. Zool. 5: 18-29.

26. T a n t o n M. T., 1969: The estimation and biology of populations of the bank vole (Clehtrionomys glareolus (Schr.)) and wood mouse (Apodemus sylvaticus (L.)). J. Anim. Ecol. 38: 511-529.

27. T a st J., 1968: Influence of the root vole, Microtus oeconomus (Pallas), upon the habitat selection, of the field vole, Microtus agrestis (L.), in northern Finland. Ann. Acad. Sci. Fenn. Ser. A. IV, 136: 1-23.

Accepted, December 3, 1975.

\section{Pentti KOSKELA i Pirkko VIRO}

\section{LICZEBNOSC, JESIENNA MIGRACJA, STRUKTURA POPULACJI I ROZMIARY CIAEA U BADYLARKI Z POENOCNEJ FINLANDII}

\section{Streszczenie}

Do badania liczebności i migracji jesiennej badylarki Micromys minutus (P a lla s, 1778) użyto specjalnego płotu (Ryc. 1). Populacja badylarki była szczególnie liczna w 1972 roku i stanowiła 63\% wszystkich osobników z 11 lowionych gatunków drobnych ssaków, zaś w 1973 roku wynosiła tylko 13\% (Ryc. 2, Tabele 1, 2). Migracja z pól, stanowiących letni biotop badylarki, na nadrzeczne ląki miała $\mathrm{w}$ obu latach miejsce $\mathrm{w}$ końcu września i początkach października (Ryc. 3), co tłumaczyć można występowaniem przymrozków. Migracje obserwuje się tylko o zmroku i nocą, przy temperaturze powyżej $0^{\circ} \mathrm{C}$, a opad śniegu i nastanie mrozów powoduje całkowite ustanie tego zjawiska.

Jesienią 1972 roku $\mathrm{w}$ populacji badylarek stwierdzono $4,4 \%$ przezimk6́w a stosunek płci w tym okresie wynosił 105:123. Ostatnia ciężarna samica została złowiona 11 października. Długość ciała badylarki waha się pomiędzy $47,0-71,0 \mathrm{~mm}$, średnia 59,1 mm; ciężar ciała $3,5-12,5 \mathrm{~g}$, średnio $6,3 \mathrm{~g}$. Srednia długość stopy wynosi $13,4 \mathrm{~mm}$, ogona $50,0 \mathrm{~mm}$ a wskaźnik długości ogona do długości ciała równa się $84 \%$ (Ryc. $4-7$, Tabela 3 ). 